\title{
Voltammetric Studies on Some Thiadiazoles and Their Derivatives
}

\author{
A. A. El Maghraby* ,G M .Abou-Elenien, N. M Rateb, and H. R. Abdel-Tawab \\ Chemistry Department, Faculty of Science, Cairo University, Giza, Egypt.
}

(Received December 4, 2008 : Accepted February 11, 2009)

\begin{abstract}
The redox characteristics of 2-arylaldehydehydrazono-3-phenyl-5-substituted-2,3-dihydro-1,3,4-thiadiazoles (1a-h) have been investigated in nonaqueous solvents such as 1,2-dichloroethane (DCE), dichloromethane (DCM), acetonitrile (AN), Tetrahydrofuran (THF), and dimethylsulfoxide (DMSO) at platinum electrode. Through controlled potential electrolysis, the oxidation and reduction products of the investigated compounds had been separated and indentified. The redox mechanism had been suggested and proved. It had been found that all the investigated compounds were oxidized in two irreversible one-electron processes following the well-known pattern of The EC-mechanism; the first electron loss gives the corresponding cation-radical which is followed by proton removal from the ortho-position in the N-phenyl ring forming the radical. The obtained radical undergoes a second electron uptake from the nitrogen in the $\mathrm{N}=\mathrm{C}$ group forming the unstable intermediate (di-radical cation) which undergoes ring closure forming the corresponding cation. The formed cation was stabilized in solution through its combination with a perchlorate anion from the medium. On the other hand, these compounds are reduced in a single two-electron process or in a successive two one-electron processes following the well known pattern of the EEC-mechanism according to the nature of the substituent; the first one gives the anion-radical followed by a second electron reduction to give the dianion which is basic enough to abstract protons from the media to saturate the $(\mathrm{C}=\mathrm{O})$ bond.
\end{abstract}

Keywords : Thiadiazoles, Cyclic voltammetry, Redox characteristics, Non-aqueous solvents, Controlled potential electrolysis.

\section{Introduction}

Thiadiazoles and their derivatives are known to have many biological applications. Recently some thiadiazoles, have been included in several compounds that have potential uses in treatment of diseases such as antiinflammatory agents, ${ }^{1)}$ anti-influenza agents ${ }^{2}$ and antiprotozoal drugs. ${ }^{3)}$ Among the compounds that deserve consideration are those used as fertilizer amendment for retarding nitrification of fertilizer $\mathrm{N}$ in soil ${ }^{4)}$ that induce acquired resistance in wheat. ${ }^{5)}$ An important potential use of these compounds is in the removal of cadmium from waste water and other potable waters. ${ }^{6}$ Because of this there are continuing interest in our laboratory in the electrochemistry of the biologically active organic compounds, ${ }^{7-16)}$ it was found worthwhile to investigate the redox characteristics of substituted thiadiazoles (la-h). These compounds were extensively

*E-mail: maghraby04@yahoo.com studied using cyclic voltammetry in nonaqueous solvents. The number of electrons participating in each electrode reaction was determined using the coulometeric technique. Separation and identification of the intermediates and the final products were made through the controlled potential electrolysis (CPE).

\section{Experimental}

The organic compounds were synthesized according to the procedure outlined in the literature. ${ }^{17)}$ All the synthesized compounds were purified by repeated crystal-<smiles></smiles> 


\begin{tabular}{|c|c|}
\hline \multirow{2}{*}{ Compounds } & Series I \\
\hline & $\mathrm{X}$ \\
\hline \multirow[t]{2}{*}{$1 \mathrm{a}$} & 1 \\
\hline & $\mathrm{Ph}-\mathrm{N}-$ \\
\hline $1 \mathrm{~b}$ & $\mathrm{H}_{3} \mathrm{C}-$ \\
\hline $1 \mathrm{c}$ & $\mathrm{Ph}-$ \\
\hline $1 \mathrm{~d}$ & Et $-\mathrm{O}-$ \\
\hline 1e & \\
\hline $1 \mathrm{f}$ & \\
\hline $1 \mathrm{~g}$ & \\
\hline
\end{tabular}

lization, dried under reduced pressure and the purity was checked by thin layer chromatography.

The measurements were carried out using the following apparatus: The EG\&G Princetion applied research model 283 Potentiostat/Galvanostat controlled from a PS-486-DX microcomputer via a National Instrument IEEE -488 through GPIB board by means of M270/250 program used for the electrochemical control.

All measurements were carried out with $2.5 \times 10^{-5} \mathrm{~mol}$ of the reactant in $15 \mathrm{ml}$ dry oxygen-free solvent with $0.1 \mathrm{~mol} \mathrm{dm}^{-3}$ tetra-n-butylammonium perchlorate as supporting electrolyte. 1,2-dichloroethane (DCE), Dichloromethane (DCM), acetonitrile (AN), tetrahydrofuran (THF) and dimethylsulfoxide (DMSO) were used as solvents.

During the solvent purification, all the processes were performed under a dry oxygen-free argon atmosphere. Fractionation was carried out using a $120 \mathrm{~cm}$ column filled with glass spirals at a recoil ratio of $50: 1$. All purified solvents were stored under argon in the dark. Purification of the different solvents was carried out as follows: $\mathrm{EtCl}_{2}$ (Merck, P.a.) was boiled for $24 \mathrm{~h}$ with $\mathrm{PCl}_{5}$ and then distilled. The main fraction was stirred with $\mathrm{KMnO}_{4}$ for $24 \mathrm{~h}$ and distilled, finally, the solvent was fractionated.

AN was purified according to the modified methods of Walter and Rumaloy [18, 19].
THF (Uvasol Merck) was boiled successively for $12 \mathrm{~h}$ with calcium hydride (Merck), $12 \mathrm{~h}$ with basic aluminium oxide (Woelm, Act. I), $6 \mathrm{~h}$ with sodium metal and $6 \mathrm{~h}$ with potassium metal and distilled after each process. In the last two steps the solvent was fractionated.

DMSO (Merck) was boiled four times with calcium hydride (Merck) for $14 \mathrm{~h}(5 \mathrm{~g} / \mathrm{L})$ and subsequently fractionated at 14 Torr. Finally, the main fraction was carefully fractionated.

The working electrode was a Pt electrode $1.3 \mathrm{~mm}$ in diameter, the auxiliary electrode was Pt wire immersed in the corresponding electrolyte. The reference electrode was $\mathrm{Ag} / \mathrm{AgCl} / \mathrm{Cl}^{-}$(sat. $\mathrm{AN}$ ) and the potential $\left(\mathrm{E}_{1 / 2}\right)$ values was referred to the redox potential of cobaltocinuim/ cobaltocene system. ${ }^{18)}$

\subsection{Controlled Potential Electrolysis (CPE)}

CPE experiments were carried out in dry acetonitrile containing $0.1 \mathrm{~mol} . \mathrm{dm}^{-3}$ tetra-n-butylammonium perchlorate (TBAP) as supporting electrolyte. Compound $1 \mathrm{~b}$ is reported here as example. The potential was controlled at the current plateau of the oxidation or reduction peaks $(300 \mathrm{mV}$ more positive or more negative than the $E_{p}$ in oxidation and reduction processes, respectively). As working electrode, a platinum gauze electrode (ca. $80 \mathrm{~cm}^{2}$ ) was used. The progress of the electrolysis was followed by recording periodically the decrease in current with time. From time to time the working electrode was removed from the cell, sprayed with pure acetone and burned in a direct flame, cooled and replaced in the cell. After the electrolysis was completed, the cell was disconnected from the circuit and the solvent was evaporated in vacuum. The residue was shaken with dry ether and the supporting electrolyte was filtered off. The ethereal layer was evaporated in turn. The obtained residue was chromatographed on thin layer silica gel plates using chloroform as an eluent. The main electrolysis product obtained was scraped off the plate and extracted with acetonitrile, filtered and evaporated in vacuum. The resulting solid compound was identified.

\subsubsection{Oxidation product of $\mathbf{1 b}$}

Oxidation of $1 \mathrm{~b}$ to give

:methyl-[5-(1-phenyl-ethylidene)-5H-3-thia1,4,5,9b-tetraazacyclopenta[a]naphthalen-2-yl]methanone (m.p.: $152{ }^{\circ} \mathrm{C}$, yield $60 \%$ ).

Analytically calculated

: C, 63.35\%; H, 4.04\%; N, 17.39\%; S, 9.94\%. 
Found

: C, 63.24\%; H, 3.98\%; N, 17.28\%; S, 9.83\%.

${ }^{1} \mathrm{H} \mathrm{NMR}\left(\mathrm{CDCl}_{3}, \mathrm{TMS}\right)$

:2.60 (s, 3H, $\left.\mathrm{CH}_{3}\right) ; 7.26-7.79$ (m, 9H, Ar H's);

$8.4(\mathrm{~s}, 1 \mathrm{H}, \mathrm{CH})$.

Mass spectrum

: Shows the main fragments at $\mathrm{m} / \mathrm{z} 321$, parent; 231

$\left[\mathrm{M}^{+}-\left(\mathrm{CH}-\mathrm{C}_{6} \mathrm{H}_{5}\right)\right] ; 203\left(\mathrm{M}^{+}-\left(\mathrm{N}_{2}\right)\right) ; 101\left(\mathrm{M}^{+}-\left[-\mathrm{C}-\mathrm{N}-\mathrm{C}_{6} \mathrm{H}_{4}\right)\right]$.

\subsubsection{Reduction product of $1 \mathrm{~b}$}

Reduction of $1 b$ to give

: (1E)-1-phenylethanone[(2E)-5-(1-hydroxy-ethyl)-3phenyl-1,3,4-thiadiazole-2(3H)-ylidene] hydrazone (m.p.: $160{ }^{\circ} \mathrm{C}$, yield 53\%).
Analytically calculated

: C, 63.91\% ; H, $5.33 \%$; N, 16.57\% ; S, 9.47\%.

Found

: C, 63.79\%; H, 5.28\%; N, 16.39\%; S, 9.38\%.

IR spectrum $(\mathrm{KBr})$ is characterized by the disappearance of the band $1678 \mathrm{~cm}^{-1}(\mathrm{C}=\mathrm{O})$ in comparison with that obtained for the original compound $1 \mathrm{~b}$.

${ }^{1} \mathrm{H}$ NMR $\left(\mathrm{CDCL}_{3}, \mathrm{TMS}\right)$

: 2,47 (s, $\left.3 \mathrm{H}, \mathrm{CH}_{3}\right) ; 2.52$ (d, $\left.3 \mathrm{H}, \mathrm{CH}_{3}\right) ; 7.26-7.98$ (m, $10 \mathrm{H}, \mathrm{Ar} \mathrm{H}$ 's); 8.4 (q, IH, CH); 11.1 (s, br., 1H, OH). Mass spectrum

: Shows the main fragments at $\mathrm{m} / \mathrm{z} 338$ parent; $234\left(\mathrm{M}^{+}-\left[-\mathrm{C}\left(\mathrm{CH}_{3}\right)_{2}\right)\right] ; 205\left(\mathrm{M}^{+}-\left(\mathrm{N}_{2}\right)\right) ; 103\left(\mathrm{M}^{+}-(-\right.$ $\left.\mathrm{C}-\mathrm{N}-\mathrm{C}_{6} \mathrm{H}_{5}\right)$ ).

Table 1. C.V. voltammetric data of compounds (1a-h) at pt-electrode in different solvents (Scan rate $=100 \mathrm{mV} / \mathrm{s}$ )

\begin{tabular}{|c|c|c|c|c|c|c|c|c|c|}
\hline \multirow{2}{*}{ Compounds } & \multirow{2}{*}{ Sol. } & \multirow{2}{*}{ D.N. } & \multirow{2}{*}{ Temp. } & \multicolumn{2}{|c|}{ Reduction } & \multicolumn{2}{|c|}{ Oxidation } & \multirow{2}{*}{$\mathrm{DE}=\mathrm{E}_{\mathrm{p}} \mathrm{O}-\mathrm{E}_{\mathrm{p}} \mathrm{R}$} & \multirow{2}{*}{$\log K$} \\
\hline & & & & $\mathrm{E}_{\mathrm{pl}}(\mathrm{V})$ & $\mathrm{E}_{\mathrm{plI}}(\mathrm{V})$ & $\mathrm{E}_{\mathrm{pl}}(\mathrm{V})$ & $\mathrm{E}_{\mathrm{plI}}(\mathrm{V})$ & & \\
\hline \multirow{5}{*}{$1 a^{*}$} & DCM & 1.000 & $0{ }^{\circ} \mathrm{C}$ & -2.054 & - & 1.272 & 1.690 & 3.326 & 56.370 \\
\hline & DCE & 0.100 & $25^{\circ} \mathrm{C}$ & -1.890 & - & 1.272 & 1.745 & 3.162 & 53.590 \\
\hline & AN & 14.100 & $25^{\circ} \mathrm{C}$ & -1.632 & - & 1.232 & 1.655 & 2.864 & 48.540 \\
\hline & THF & 20.000 & $0{ }^{\circ} \mathrm{C}$ & -1.833 & - & 1.560 & - & 3.393 & 57.518 \\
\hline & DMSO & 29.800 & $25^{\circ} \mathrm{C}$ & -1.800 & - & 1.300 & - & 3.100 & 52.541 \\
\hline \multirow{5}{*}{$1 b$} & DCM & 1.000 & $0{ }^{\circ} \mathrm{C}$ & -1.708 & - & 1.250 & 1.617 & 2.958 & 50.125 \\
\hline & DCE & 0.100 & $25^{\circ} \mathrm{C}$ & -1.678 & - & 1.232 & 1.642 & 2.910 & 49.321 \\
\hline & AN & 14.100 & $25^{\circ} \mathrm{C}$ & -1.530 & - & 1.278 & 1.694 & 2.808 & 47.590 \\
\hline & THF & 20.000 & $0{ }^{\circ} \mathrm{C}$ & -1.768 & - & 1.477 & - & 3.245 & 54.995 \\
\hline & DMSO & 29.800 & $25^{\circ} \mathrm{C}$ & -1.500 & - & 1.275 & - & 2.775 & 47.030 \\
\hline \multirow{5}{*}{$1 \mathrm{c}$} & DCM & 1.000 & $0{ }^{\circ} \mathrm{C}$ & -1.490 & -2.127 & 1.345 & 1.690 & 2.835 & 48.050 \\
\hline & DCE & 0.100 & $25^{\circ} \mathrm{C}$ & -1.420 & -2.070 & 1.285 & 1.750 & 2.705 & 45.840 \\
\hline & $\mathrm{AN}$ & 14.100 & $25^{\circ} \mathrm{C}$ & -1.294 & -2.102 & 1.290 & 1.690 & 2.584 & 43.790 \\
\hline & THF & 20.000 & $0{ }^{\circ} \mathrm{C}$ & -1.700 & - & 1.500 & - & 3.200 & 54.242 \\
\hline & DMSO & 29.800 & $25^{\circ} \mathrm{C}$ & -1.230 & - & 1.340 & - & 2.570 & 43.550 \\
\hline \multirow{5}{*}{$1 d$} & DCM & 1.000 & $0{ }^{\circ} \mathrm{C}$ & -2.072 & - & 1.345 & 1.763 & 3.417 & 57.910 \\
\hline & DCE & 0.100 & $25^{\circ} \mathrm{C}$ & -2.000 & - & 1.303 & 1.696 & 3.303 & 55.980 \\
\hline & AN & 14.100 & $25^{\circ} \mathrm{C}$ & -1.780 & - & 1.268 & 1.692 & 3.048 & 51.660 \\
\hline & THF & 20.000 & $0^{\circ} \mathrm{C}$ & -2.218 & - & 1.600 & - & 3.818 & 64.710 \\
\hline & DMSO & 29.800 & $25^{\circ} \mathrm{C}$ & -1.730 & - & 1.340 & - & 3.070 & 52.030 \\
\hline \multirow{5}{*}{$1 \mathrm{e}$} & DCM & 1.000 & $0{ }^{\circ} \mathrm{C}$ & -1.418 & -2.181 & 1.407 & 1.781 & 2.825 & 47.880 \\
\hline & DCE & 0.100 & $25^{\circ} \mathrm{C}$ & -1.418 & -2.140 & 1.290 & 1.690 & 2.708 & 45.890 \\
\hline & $\mathrm{AN}$ & 14.100 & $25^{\circ} \mathrm{C}$ & -1.296 & -2.104 & 1.272 & 1.680 & 2.568 & 43.500 \\
\hline & THF & 20.000 & $0{ }^{\circ} \mathrm{C}$ & -1.918 & - & 1.540 & - & 3.458 & 58.610 \\
\hline & DMSO & 29.800 & $25^{\circ} \mathrm{C}$ & -1.150 & - & 1.310 & - & 2.460 & 41.689 \\
\hline \multirow{5}{*}{$1 f^{* *}$} & DCM & 1.000 & $0{ }^{\circ} \mathrm{C}$ & -1.454 & -2.072 & 1.345 & 1.763 & 2.799 & 47.440 \\
\hline & DCE & 0.100 & $25^{\circ} \mathrm{C}$ & -1.500 & -2.125 & 1.267 & 1.642 & 2.767 & 46.894 \\
\hline & $\mathrm{AN}$ & 14.100 & $25^{\circ} \mathrm{C}$ & -1.270 & -2.064 & 1.296 & 1.712 & 2.566 & 43.490 \\
\hline & THF & 20.000 & $0{ }^{\circ} \mathrm{C}$ & -1.900 & - & 1.400 & - & 3.300 & 55.930 \\
\hline & DMSO & 29.800 & $25^{\circ} \mathrm{C}$ & -1.210 & - & 1.350 & - & 2.560 & 43.390 \\
\hline
\end{tabular}




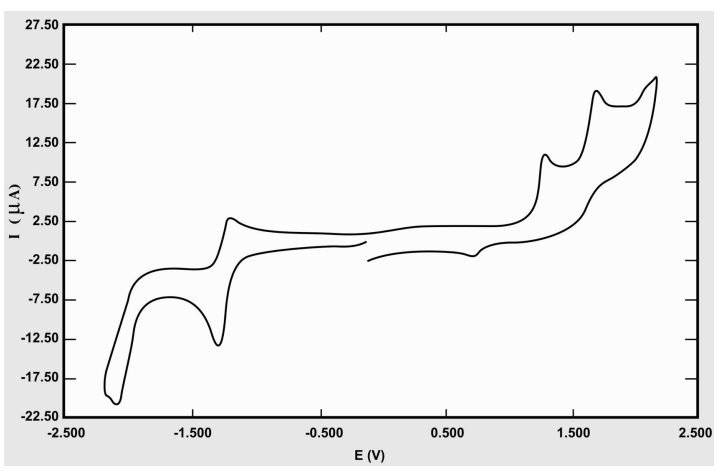

Fig. 1. CV-voltammogram of compound 1c in $\mathrm{AN}$ at Ptelectrode (scan rate $=100 \mathrm{mV} / \mathrm{s} ; \mathrm{T}=25^{\circ} \mathrm{C}$ ).

\section{Results and Dicussion}

Cyclic voltammetric data listed in Table 1. Fig. 1 shows as an example the cyclic voltammogram of some investigated compounds. Compounds (1a-h) were oxidized in two irreversible one-electron processes following the well-known pattern of EC-mechanism. The first electron is followed by proton removal from the ortho-position in the N-phenyl ring forming the radical, this is followed by the second electron uptake from the second nitrogen atom in the $\mathrm{N}=\mathrm{C}$ group forming the unstable intermediate (di-radical cation) which undergoes ring closure forming the corresponding cation. The formed cation can be stabilized in solution through its combination with a perchlorate anion from the medium. Compounds which contain the $\mathrm{NH}$ group (1a and 1f) undergo further oxidation. The NH is oxidized through electron uptake followed by proton-removal to give the corresponding radical, which undergoes a dimerization reaction to give the bis compound (Scheme 1). On the other hand, the reduction center in the investigated compounds seems to be the carbonyl group $(\mathrm{C}=\mathrm{O})$. The absence of this group in compound $1 \mathrm{~h}$ is the reason for the disappearance of reduction peaks. In quasi-reversible one electron processes, these compounds are reduced to give the more or less stable anion-radical. The stability of this anion-radical can be seen from the shape of the reduction peak and from the values of $\Delta \mathrm{E}_{\mathrm{p}}$ and $\mathrm{I}_{\mathrm{p}}^{\mathrm{c}} / \mathrm{I}_{\mathrm{p}}^{\mathrm{a}}$. The increase of the withdrawing power of the substituent, makes possible for a second electron reduction wave to give the dianion, which is basic enough to abstract protons from the media to saturate the $(\mathrm{C}=\mathrm{O})$ bond (Scheme 1).

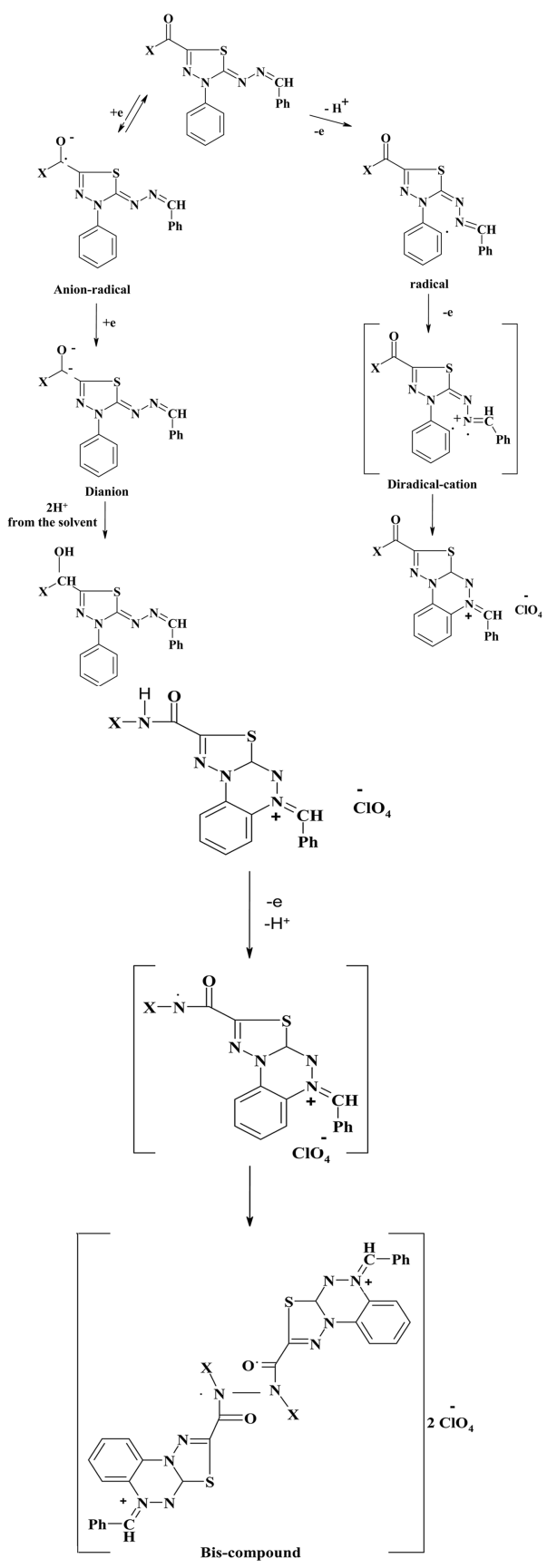

\subsection{Substituent Effect}

The effect of substituents on both oxidation and reduction of an electroactive site can be illustrated by applying the well-known modified Hammett equation of the form. $^{21)}$

$$
E_{p}^{*}=\rho_{x} \sigma_{x}+E_{p}^{H}
$$



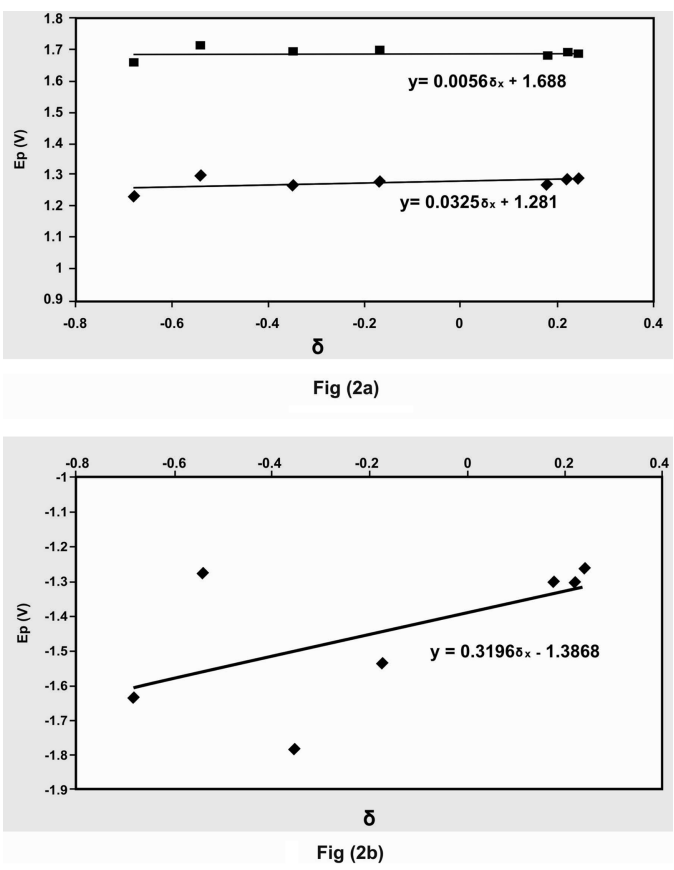

Fig. 2. (a) Dependence of $E_{p}(o x)$ of compound (1a-h) in AN on Hammett substitution constant $(\sigma)$, (b) Dependence of $E_{p}$ (red) of compound (1a-h) in AN on Hammett substitution constant $(\sigma)$.

Where $\sigma_{\mathrm{x}}$ is the Hammett constant, $\rho_{\mathrm{x}}$ is the polarographic reduction or oxidation constant and $\mathrm{E}_{\mathrm{p}}^{*}, \mathrm{E}_{\mathrm{p}}^{\mathrm{H}}$ are the peak potentials of the substitued and unsubstituted compounds, respectively. Fig. 2(a), (b) illustrate the Hammett equation correlations of the peak potentials of compounds (1a-h) for both oxidation and reduction processes. The equations of the regression lines obtained for the series (1a-h) are listed in Table 2.

It is obvious from equations in Table 2 that the magnitude of the oxidation constant $\rho_{\mathrm{x}}^{\mathrm{ox}}$ is smaller than that of the corresponding reduction constant $\rho_{\mathrm{x}}^{\text {red }}$. This indicates that the electroreduction is much more susceptible to substituent effect than electroxidation. This fact implies that, there is more significant resonance interaction between the substituent and the $\mathrm{C}=\mathrm{O}$ group which is in good agreement with the proposed reduction of adjacent $\mathrm{C}=\mathrm{O}$ group.

To show the effect of solvent on the redox mode of the investigated compounds, the electrochemical characteristics of these compounds are extensively studied in 1,2-dichloroethane (DCE), dichloromethane (DCM), acetonitrile (AN), tetrahydrofuran (THF) and dimethylsulfoxide (DMSO) with $0.1 \mathrm{~mol} \mathrm{dm}^{-3}$ tetra-
Table 2. The Hammett equations of the regression lines obtained for the series (1a-h).

\begin{tabular}{|c|c|}
\hline Solvent & Equation of series $1 \mathrm{a}-\mathrm{h}$ \\
\hline AN & $\begin{array}{l}\left.\left(\mathrm{E}_{\mathrm{p}}{ }^{\mathrm{ox}}\right)_{\mathrm{I}}=0.0325 \sigma_{\mathrm{x}}+1.2810 \text { (Oxidation) }\right)_{\mathrm{I}} \\
\left.\left(\mathrm{E}_{\mathrm{p}}{ }^{0 \mathrm{x}}\right)_{\mathrm{II}}=0.0056 \sigma_{\mathrm{x}}+1.6880 \text { (Oxidation) }\right)_{\mathrm{II}} \\
\left(\mathrm{E}_{\mathrm{p}}^{\text {red }}\right)=0.3169 \sigma_{\mathrm{x}}-1.3868 \text { (Reduction) }\end{array}$ \\
\hline DCE & $\begin{array}{l}\left(\mathrm{E}_{\mathrm{p}}{ }^{0 \mathrm{x}}\right)_{\mathrm{I}}=0.0336 \sigma_{\mathrm{x}}+1.2876(\text { Oxidation })_{\mathrm{I}} \\
\left.\left.\left(\mathrm{E}_{\mathrm{p}}{ }_{\mathrm{I}}\right)_{\mathrm{II}}=0.0545 \sigma_{\mathrm{x}}+1.7150 \text { (Oxidation) }\right)_{\mathrm{II}}\right) \\
\left(\mathrm{E}_{\mathrm{p}}{ }^{\text {red }}\right)=0.4513 \sigma_{\mathrm{x}}-1.5468 \text { (Reduction) }\end{array}$ \\
\hline DCM & $\begin{array}{l}\left.\left(\mathrm{E}_{\mathrm{p}}{ }^{\mathrm{ox}}\right)_{\mathrm{I}}=0.0856 \sigma_{\mathrm{x}}+1.3485 \text { (Oxidation) }\right)_{\mathrm{I}} \\
\left.\left(\mathrm{E}_{\mathrm{p}}{ }^{\mathrm{ox}}\right)_{\mathrm{II}}=0.0295 \sigma_{\mathrm{x}}+1.7311 \text { (Oxidation) }\right)_{\mathrm{II}} \\
\left(\mathrm{E}_{\mathrm{p}}{ }^{\text {red }}\right)=0.5156 \sigma_{\mathrm{x}}-1.5781 \text { (Reduction) }\end{array}$ \\
\hline THF & $\begin{array}{l}\left(\mathrm{E}_{\mathrm{p}}^{\mathrm{ox}}\right)=0.0226 \sigma_{\mathrm{x}}+1.5033 \text { (Oxidation) } \\
\left(\mathrm{E}_{\mathrm{p}}^{\text {red }}\right)=0.1079 \sigma_{\mathrm{x}}-1.874 \text { (Reduction) }\end{array}$ \\
\hline DMSO & $\begin{array}{l}\left(\mathrm{E}_{\mathrm{p}}{ }^{\mathrm{x}}\right)=0.0135 \sigma_{\mathrm{x}}+1.3257 \text { (Oxidation) } \\
\left(\mathrm{E}_{\mathrm{p}}^{\text {red }}\right)=0.5028 \sigma_{\mathrm{x}}-1.3257 \text { (Reduction) }\end{array}$ \\
\hline
\end{tabular}

n-butylammonium perchlorate as supporting electrolyte. The voltammetric data are listed in Table 1. As shown by the data and voltammograms, compounds (1a-h), both oxidation and reduction of all the investigated compounds proceed identically in DCE, DCM and AN, they are oxidized in two irreversible one-electron processes to the diradical cation which in turn undergoes a follow up chemical reaction with ring closure; and are reduced in one or two-electron processes to the stable anion radical or to the full saturation of the $(\mathrm{C}=\mathrm{O})$ group according to the nature of the substituent (Scheme 1). The requirements for reversibility in the reduction process are satisfied, at least at low scan rates, in the three solvents for the compounds which undergo a reversible or quasireversible reduction. In THF and DMSO (Fig. 3), the oxidation and also the reduction proceed in a one twoelectron wave. The radical or the anion-radical formed during the first electron lost or gained are unstable, therefore the second electron transfer follows immediately. Going from DCE to DMSO (increasing the donor number from 0.1 to 29.8 ), ${ }^{22)}$ makes both the oxidation and reduction of these thiadiazoles easier. This behavior can be attributed to a solvation effect, as previously reported by many workers. ${ }^{22-24)}$ Fig. 4 , represents the relationship between $\Delta \mathrm{E}_{\mathrm{p}}$ of compound $1 \mathrm{~d}$ and the donor number of the solvents.

According to the Born-Haber cycle ${ }^{25}$ the $\mathrm{E}_{\mathrm{p}}$ values for one thiadiazole in two different solvents $\mathrm{A}$ and $\mathrm{B}$ and the salvation energies of the corresponding ions can be derived as follows:

$$
\begin{aligned}
& \mathrm{F}\left(\Delta \mathrm{E}_{\mathrm{p}}^{\mathrm{ox}}-\Delta \mathrm{E}_{\mathrm{p}}^{\mathrm{red}}\right) \\
& =\mathrm{F}\left\{\left[\mathrm{E}_{\mathrm{p}}^{\mathrm{ox}}(\mathrm{A})-\mathrm{E}_{\mathrm{p}}^{\mathrm{ox}}(\mathrm{B})\right]-\left[\mathrm{E}_{\mathrm{p}}^{\mathrm{red}}(\mathrm{A})-\mathrm{E}_{\mathrm{p}}^{\mathrm{red}}(\mathrm{B})\right]\right\} \\
& =\mathrm{F}\left\{\left[\mathrm{E}_{\mathrm{p}}^{\mathrm{ox}}(\mathrm{A})-\mathrm{E}_{\mathrm{p}}^{\mathrm{red}}(\mathrm{A})\right]-\left[\mathrm{E}_{\mathrm{p}}^{\mathrm{ox}}(\mathrm{B})-\mathrm{E}_{\mathrm{p}}^{\mathrm{red}}(\mathrm{B})\right]\right\}
\end{aligned}
$$




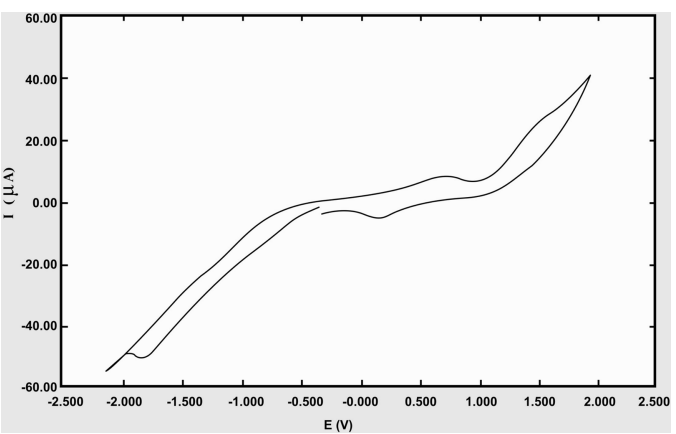

Fig. 3. CV-voltammogram of compound $1 \mathrm{a}$ in THF at Pt-electrode (scan rate $=100 \mathrm{mV} / \mathrm{s} ; \mathrm{T}=25 \mathrm{oC}$ ).

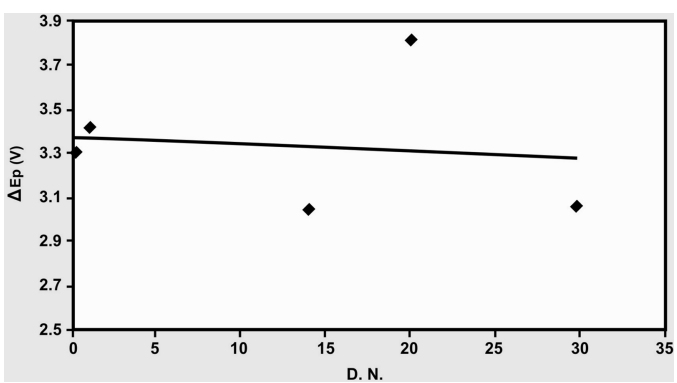

Fig. 4. Dependence of $\Delta \mathrm{Ep}$ of compound $1 \mathrm{~d}$ on the donor number of the solvents.

$$
\begin{aligned}
= & -\delta \Delta \mathrm{G}_{\text {solv }}\left(\mathrm{TD}^{+}, \mathrm{A}\right)+\delta \Delta \mathrm{G}_{\text {solv }}\left(\mathrm{TD}^{+}, \mathrm{B}\right) \\
& -\delta \Delta \mathrm{G}_{\text {solv }}\left(\mathrm{TD}^{-}, \mathrm{A}\right)+\delta \Delta \mathrm{G}_{\text {solv }}\left(\mathrm{TD}^{-}, \mathrm{B}\right) \\
= & {\left[\delta \Delta \mathrm{G}_{\text {solv }}\left(\mathrm{TD}^{+}, \mathrm{B}\right)+\delta \Delta \mathrm{G}_{\text {solv }}\left(\mathrm{TD}^{-}, \mathrm{B}\right)\right] } \\
& {\left[\delta \Delta \mathrm{G}_{\text {solv }}\left(\mathrm{TD}^{+}, \mathrm{A}\right)+\delta \Delta \mathrm{G}_{\text {solv }}\left(\mathrm{TD}^{-}, \mathrm{A}\right)\right] }
\end{aligned}
$$

where TD represents the thiadiazole derivative, $\delta \Delta \mathrm{G}_{\text {solv }}$ is the differential Gibbs solvation energy, $\mathrm{F}$ is the faraday constant and $E_{p}^{o x}-E_{p}^{r e d}=\Delta E_{p}$ is the difference between the oxidation and reduction peaks potential in the same solvent. According to the equation, when the solvent is changed the sum of the solvation energies is greater if the difference $\Delta \mathrm{E}_{\mathrm{p}}$ is smaller. As can be seen in table $1 ; \Delta \mathrm{E}_{\mathrm{p}}$ for all the investigated thiadiazoles (1a-h) decreased when the solvent changed from 1,2-dichloroethane to DMSO; i.e. the sum of the solvation energies increased which is in full agreement with rhe results obtained for hydrazyl. ${ }^{20-22)}$ This is in accordance with Gutmann's donor model. ${ }^{22)}$ In all cases there is a linear relationship between the electrochemical parameters $\left(\mathrm{E}_{\mathrm{p}}, \Delta \mathrm{E}_{\mathrm{p}}\right.$ and $\left.\log \mathrm{k}\right)$ and the donor number (Fig. 4). Accordingly, the sum of the solvation energies of a particular thiadiazole in a given solvent depends on the donor number of the solvent. This suggests that the solvation process is mainly attributable to electrostatic interaction. It is possible that the unusual results for the oxidation and reduction of all the investigated thiadiazoles in THF is due to perturbation of the solvent by, for example, formation of an ion pair [20, 26, 27]. On the basis of substituent dependence it is expected that the oxidation potential will decrease, while the reduction potentiall will increase, when the substituent is less electronegative. Also, the solvation of the formed ion radical of two different substituted thiadiazoles in the same solvent can be expressed as follows according to the principle of the cyclic process. ${ }^{24)}$

$$
\begin{aligned}
& F\left\{\left[E_{p}^{o x}-E_{p}^{\text {red }}\right]_{1 b}-\left[E_{p}^{o x}-E_{p}^{\text {red }}\right]_{1 c}\right\} \\
& \quad=\left[\delta \Delta G_{\text {solv }}(1 b)^{+}+\delta \Delta G_{\text {solv }}(1 b)^{-\cdot}\right] \\
& {\left[\delta \Delta G_{\text {solv }}(1 \mathrm{c})^{+}+\delta \Delta G_{\text {solv }}(1 \mathrm{c})^{-\cdot}\right]}
\end{aligned}
$$

This can only be applied if $I(R)-E_{A}(R)$ is a constant, where $I$ is the ionization potential and $E_{A}$ is the electron affinity. Table 1 shows a regular increase in $\Delta \mathrm{E}_{\mathrm{p}}$ for the compounds using different solvents. Taking in consideration the allowed experimental error, the increase in $\ddot{\mathrm{A}} \mathrm{E}_{\mathrm{p}}$ follows the order:

$\left(\Delta \mathrm{E}_{\mathrm{p}}\right)_{1 \mathrm{~d}} \approx\left(\Delta \mathrm{E}_{\mathrm{p}}\right)_{1 \mathrm{a}}>\left(\Delta \mathrm{E}_{\mathrm{p}}\right)_{1 \mathrm{~b}}>\left(\Delta \mathrm{E}_{\mathrm{p}}\right)_{1 \mathrm{c}} \approx\left(\Delta \mathrm{E}_{\mathrm{p}}\right)_{1 \mathrm{e}}$ $\left(\Delta \mathrm{E}_{\mathrm{p}}\right)_{1 \mathrm{f}} \approx\left(\Delta \mathrm{E}_{\mathrm{p}}\right)_{1 \mathrm{~g}}$

i.e. the sum of the solvation energies for compounds in series (1a-h) increases in the order: ic $1 \mathrm{e} 1 \mathrm{~g}$ $1 \mathrm{f}>1 \mathrm{~b}>1 \mathrm{a} 1 \mathrm{~d}$

This can be explained from the fact that the substitutents are far away from the oxidation center of the molecules and they only affect the reduction process, which is in full agreement with the proposed mechanism. Assuming that the difference in the ionization potentials is small, the change of the solvation energies of the different investigated compounds in different solvents that obtained are listed in Table 3.

Table 3. Difference in solvation energies of one thiadiazole ion radical in two different solvents at $25^{\circ} \mathrm{C}$.

\begin{tabular}{cccccccc}
\hline \multirow{2}{*}{ Solvent transition } & \multicolumn{7}{c}{$\mathrm{F}\left(\mathrm{DE}_{\mathrm{p}}\right)_{\mathrm{A}}-\mathrm{F}\left(\mathrm{DE}_{\mathrm{p}}^{\prime}\right)_{\mathrm{A}}$ in two different solvents } \\
\cline { 2 - 7 } & $1 \mathrm{a}$ & $1 \mathrm{~b}$ & $1 \mathrm{c}$ & $1 \mathrm{~d}$ & $1 \mathrm{e}$ & 1f & $1 \mathrm{~g}$ \\
\hline DCM DCE & $\mathrm{F}(164)$ & $\mathrm{F}(048)$ & $\mathrm{F}(130)$ & $\mathrm{F}(114)$ & $\mathrm{F}(117)$ & $\mathrm{F}(032)$ & $\mathrm{F}(054)$ \\
DCE AN & $\mathrm{F}(298)$ & $\mathrm{F}(237)$ & $\mathrm{F}(121)$ & $\mathrm{F}(255)$ & $\mathrm{F}(140)$ & $\mathrm{F}(201)$ & $\mathrm{F}(193)$ \\
DCM AN & $\mathrm{F}(462)$ & $\mathrm{F}(015)$ & $\mathrm{F}(251)$ & $\mathrm{F}(369)$ & $\mathrm{F}(257)$ & $\mathrm{F}(304)$ & $\mathrm{F}(247)$ \\
\hline
\end{tabular}




\section{References}

1. D. G. Ropertson, G. Loewen, K. M. Walsh, L. A. Dethloff, R. S. Sigler. M. A. Dominick, and E. R. Urda; Fundam Appl. Toxicol. 20(4) 446 (1993).

2. J. M. Collaino, G. M. Birch, and J. C. Tang; Antiviral Chem.Chlemother., 4(5) 271 (1993).

3. J. Karoflak-wojciechowska, A. Mrozek, Amiel, Pascale, Brouant, Pierre, and J. Barbe, Acta crystallographica, Section C Crystal structure Communincations, 52(11) 2939 (1996).

4. G. W. McCarty and M. J. Bremner, Soil Sci. Soc. Am. J., 54(4) 1017 (1990).

5. J. Goerlach, S. Volrath, G. Knuaf-Beiter, G. Hengy, V. Beckhove, K.H. Kogel, M. Oestendrop, T. Staub, and J. Ryals, et al. plant Cell., 8(4) 629 (1996).

6. M. J. Hudson, M. B. Hassan, and G. Tiravanti, Hydrometallurgy, 24(2) 249 (1990).

7. G. M. Abou-Elenien, N. A. Ismail, T. S. Hafez, Bull. Chem. Soc. Jpn., 64651 (1991)

8. G. M. Abou-Elenien, M. A. Aboutable, A. O. Sherin, and H. M. Fahmy, J. Chem. Soc. Perkin Trans II, 377 (1991).

9. G. M. Abou-Elenien, N. A. Ismail, and A. A. Magd Eldin, Monatsh. Chem., 1231117 (1992).

10. G. M. Abou-Elenien, J. Electroanal. Chem., 346367 (1993).

11. G. M. Abou-Elenien, A. A. El Maghraby, and H. R. AbdelTawab. Electroanalysis, 13(7) 587 (2001).

12. G. M. Abou-Elenien, A. O. Abdelhamid, N. A. Ismail, A. A. El Maghraby, and M. A. I. El-Hamadi., Electrochemistry, 69(9), $652(2001)$.
13. G. M. Abou-Elenien, N. A. Ismail, A. A. El Maghraby, and G. M. Al Abdallah, Electroanalysis, 13(12), 1022 (2001).

14. G. M. Abou-Elenien, N. A. Ismail, A. A. El Maghraby, and M. A. I. El-Hamadi., Electroanalysis, 14(14), 998 (2002).

15. A. A. El Maghraby, G. M. Abou- Elenien, N. A Abdel Reheem, and H. R. Abdel-Tawab, J. Korean. Chem. Society, 50(4) 307 ( 2006).

16. A. A. El Maghraby, G. M. Abou- Elenien, and K. I. Shehata, J.Korean Electrochemical Society, 10(3) 159 (2007).

17. H. F. Zohdi, N. M. Rateb, M. M. Sallam, and A. O. Abdel Hamid, J. Chem. Res., 1998, (S) 742 (M) 3329.

18. M. Walter, L. Rumaloy, Anal. Chem., 45165 (1973).

19. G. M. Abou-Elenien, Ph. D. thesis, Freiburg, Germany (1980).

20. G. M. Abou-Elenien, J. Electroanal. Chem., 345303 (1993).

21. H. H. Jaffe, Chem. Rev., 53191 (1953).

22. V. Gutmann, Monatsh. Chem., 104990 (1973).

23. I. V. Nelson, and R. T. Iwamoto, Anal. Chem., 331795 (1961).

24. V. Gutmann and R. Schmid, Monatsh. Chem., 1002113 (1969).

25. B. Case, N. S. Hush, and R. Parsons, J. Electroanal. Chem., 10360 (1965).

26. S. Patai (ed) "The Chemistry of Ether linkage" Interscience, London, Ch 6 (1967).

27. S. Searles Jr. and M. Tamres, "Basicity and Complexing Ability of Ethers" Interscience, London, PP, 1967, 295. 